\title{
The Mediating Role of Job Satisfaction in the Development of Officer's Performance
}

\author{
Muhammad Ridha, Mahfudnurnajamuddin, Baharuddin Semmaila, and Mursalim Mursalim
}

\begin{abstract}
This study aims to examine the effect of the work environment, compensation on job satisfaction, and officer performance. This research was conducted in eight Public Health Centers in Pinrang Regency with a population of 322 people; researchers took 220 people as samples. This research method uses regressive research with a quantitative approach. The technique of collecting data by making observations with the media questionnaire. The method of analysis uses inferential statistics with a parametric data type and uses Structural Equation Modeling (SEM). The results showed that the work environment variable on employee performance had a positive and significant effect because it had $t$-value $=2.97$ > 1.96 (t-table). Likewise, the work environment on job satisfaction has at-value $=2.31>1.96(t$-table) which means that the work environment has a positive and significant effect on job satisfaction. The work environment on employee performance mediated by job satisfaction also has a significant effect with $t$-value $=-2.32>1.96$ (t-table). However, the compensation variable on employee performance shows no and significant effect because the $t$-value $=0.00<1.96$ ( $t$-table). The compensation variable on job satisfaction has a positive and significant effect with $t$-value $=2.97>1.96$ (t-table). Likewise, the compensation variable on employee performance with job satisfaction as a mediating variable has at-value $=3.36>1.96(t-$ table) which means that positive job satisfaction mediates the relationship between compensation and employee performance. With $t$-value $=\mathbf{- 2 . 7 3}>1.96$ (t-table), so it can be interpreted that the job satisfaction variable has a positive and significant effect on officer performance.
\end{abstract}

Index Terms-Work environment, compensation, job satisfaction, officer performance.

\section{INTRODUCTION}

The public health level in Pinrang Regency has not reached the expected phase. The morbidity rate of Pinrang Regency based on the National Socio-Economic Survey in 2016 amounted to $24,43 \%$. The morbidity rate still tends to be high. However, this figure tends to increase when compared to 2015 which amounted to $33.99 \%$, an increase of $9.56 \%$. One of the factors that cause a high rate of mobility is the quality of health services [1].

Furthermore, according to data from the Pinrang District Health Office, through the 2017 Healthy Living Society Movement report, it is known that the life expectancy of the Pinrang Regency community has fluctuated. From 2009 to 2016 the life expectancy tended to increase, from 71.00 in

Published on September 20, 2020.

Muhammad Ridha, Indonesian Muslim University of Makassar, Indonesia. (e-mail: muhammadridha96@yahoo.co.id)

Mahfudnurnajamuddin, Indonesian Muslim University of Makassar, Indonesia.

Baharuddin Semmaila, Indonesian Muslim University of Makassar, Indonesia.

Mursalim Mursalim, Indonesian Muslim University of Makassar, Indonesia.
2009 to 72.00 in 2013. However, it decreased drastically in 2014 to 67,90 to 68,50 in 2016. Furthermore, related to health services. Three main factors become the focus of attention, namely the number of health facilities, the quality of health facilities, and the quality of health personnel (officers). In Pinrang Regency, health service facilities have met national standards both in terms of quantity and quality.

However, the quality and quantity of health personnel at the Community Health Center itself still requires serious attention because the expected work results have not been fulfilled. When viewed from the number of medical personnel (officers), in 2016 there were 75 medical personnel (43 general practitioners, 20 dentists, and 12 specialists), 153 midwives, 266 nurses, 26 community pharmacists, and 160 other health workers. The total number of health workers reached 668 people.

The ratio of population to doctors in 2016 was 1: 4,927. This means that each doctor must serve around 4,927 residents. This means that the number of doctors in Pinrang Regency still needs to be increased because the growth of the occupation is going very well. Meanwhile, the increase in the number of medical personnel (officers) is not comparable [2]. Related to the quality of service, the factor of labor or officers at the Public Health Center becomes important predictions that need to be considered such as work environment and compensation, performance, and job satisfaction of officers. If one of these factors is not met, it is very possible that health services from health workers to the community in Pinrang Regency will not be optimal.

Performance or work performance itself is still influenced by the work environment and compensation. The environment in this case is everything that is directly involved with workers at work such as workspaces, coworkers, or work facilities, and infrastructure. The better of work environment can be better the chances of producing good performance. Likewise with the compensation that must be obtained by officers. The better the compensation system that is run by an organization, the better the performance that will be generated by the workers [3]-[8].

The result of performance is the self-efficacy value shown by the worker. If the work performance is following the expectations, it will trigger good job satisfaction as well. Workers who have good job satisfaction will have good job pride and loyalty as well so that a work cycle will emerge which in turn results in better performance.

Studies related to job satisfaction have also been carried out by several foreign researchers such as [9]-[14] that workers with high levels of job satisfaction have pride and high job loyalty so that it has an impact on the work cycle which in turn results in high performance. 


\section{LITERATURE REVIEW}

\section{A. Working Environment}

The environment is the total number of all conditions that affect the existence of the growth and welfare of an organism on earth [15]. The environment is an interaction of physical systems, biology, and cultural elements that are interconnected in various ways, either individually or collectively [16]. In the Law of the Republic of Indonesia Number 32 of 2009 concerning Protection and Management of the Environment, defines the environment as a spatial unit with all objects, power, conditions, and living things, including humans and their behavior, which affect the continuity and welfare of humans and other creatures [17]. It must be realized that the human relationship with the environment is circular [18]. This means that all forms of action or treatment given by humans to the environment, then the impact will return to humans themselves.

The good environmental qualities standards will make people feel at home or feel at home in that environment [18]. The environmental behavior is influenced by several factors such as subjective norms, behavioral beliefs, and the existence of control that comes from behavior and opportunities [19]. The work environment in a company or organization is very important for management to pay attention to. Even though the work environment does not carry out the production process in a company, the work environment has a direct influence on the employees who carry out the production process. The work environment is an atmosphere where employees carry out activities every day.

The work environment also colors the culture or characteristics of the workers in it by referring to; there is a relationship between the work environment and the workers in it; there is a relationship between workplace culture and the behavior and attitudes of workers; worker's behavior and attitudes affect performance; there will be a culture shock for each individual who has a different work culture if they have to work in one organizational group [20]. The work environment is everything that is around the employee and can affect carrying out the duties assigned to him, for example by the presence of an air conditioner (AC), adequate lighting, and so on [21].

The work environment is something that is in the worker's environment that can influence several things must, in carrying out tasks such as temperature, humidity, ventilation, lighting, noise, cleanliness of the workplace and whether or not work equipment is adequate [22]. The work environment can be interpreted as a whole tooling tool faced, the surrounding environment where a person works, his work methods, as the influence of his work both as individuals and as a group [23]. Meanwhile, according to [24] the work environment is an environment where employees do their daily work. Organizational work environment factors greatly support individuals in achieving the expected work performance [25].

The organizational environmental factors referred to include clear job descriptions, adequate authority, challenging work targets, effective work communication patterns, harmonious working relationships, a dynamic and reflex work climate, career opportunities and adequate work facilities. To create a good work environment there are several things that must be considered [26], namely: (1) Workplace buildings, (2) spacious workspaces, (3) Air exchange ventilation, (4) Availability of places religious worship, and (5) The availability of special and public transportation facilities for employees who are comfortable and easy.

According to [27] in general, the type of work environment is divided into two factors, namely physical work environment factors and non-physical work environment factors. Physical work environment factors include; coloring, lighting, air, noise, space to move, security, and cleanliness. Meanwhile, non-physical work environment factors include; work structure, work responsibilities, attention and support from leaders, cooperation between groups, and good communication.

The work environment indicators according to [28] are as follows: lighting, work temperature, humidity, air circulation, mechanical vibrations, unpleasant odors, coloring, decoration, music and Safety at workplaces.

The hypotheses in this study are as follows:

$\mathrm{H}_{1} \quad$ Work environment has a positive and significant effect on officer performance

$\mathrm{H}_{2}$ Work environment has a positive and significant effect on job satisfaction.

$\mathrm{H}_{3}$ Work environment has a positive and significant effect on officer performance mediated by job satisfaction.

\section{B. Compensation}

Some scholars explain that leaders are agents of change, people whose actions affect others more than the actions of others affect them. In other words, leaders have a greater ability to direct or move other people than others who do not have the status of leaders towards others, also explain leaders as the future of the organization, namely to build and strengthen their organizations [29]. From these two views it can be explained that a leader is someone with the ability and influence to empower resources and move others to achieve the goals set.

A leader as someone who can lead, namely the ability to influence the behavior of others. There are 18 characteristics of a leader [27] including; broad general educators, develop mentally, high curiosity, analytical abilities, a strong memory, integrative capabilities, communication skills, educational skills, rational and objective, pragmatic, sense of urgency, cohesiveness, relevance, smart, courageous, adaptive and flexible, and hearing [27].

In general, there are two main tasks for a leader, namely completing a job and doing teamwork [29]. For the task of completing a job, the leader role must be able to complete jobs to produce the desired goals following pre-determined standards. The work to be completed must be measured with time, which means that each job has clear boundaries about when and convey the work to be done, so that the work can be pursued following the Beside scan, the specified time. Furthermore, the task of doing teamwork of a leader must empower human resources as a driving factor in completing work.

Role is the part played by an individual in helping the group solves problems in achieving its goals [30]. Roles include activities that are expected to be carried out by someone [31]. In addition, the role (role) is defined as a 
pattern of actions that are expected of someone in the act of involving others; like that a leader is able to create the future through group collaboration [32], [33].

There are four limitations on the role of a leader, namely; leader is a role model or role model, pioneer or who creates a vision, discipline, and passionate or empowering provider [34]. Not only that, but [35] also states that the main role of a leader is to manage his character, integrity, humility, knowledge, words and actions. The essence of the role of a leader is to provide useful added value and help groups, organizations and society in achieving their goals [29].

The definition of compensation according to [36] comes from the word "leads" which contains two main things, namely; the leader as the subject, and being led as an object. The word leader contains the meaning of directing, building or managing, guiding, and also showing or influencing. Leaders have responsibility both physically and spiritually for the success of the work activities they lead so that being a leader is not easy and not everyone will have the same in carrying out compensation.

The term compensation (leadership) in technical vocabulary is derived from general vocabulary so that it is still ambiguous [37]. Several definitions of compensation are, forward by several experts. The compensation is the behavior of certain individuals (who are used as leaders) who direct group activities to achieve common goals. In this case compensation occurs in a group of people who have the same goal [38].

The compensation is carried out when a person mobilizes institutionally, politically, psychologically, and elements or other sources to generate, involve, and fulfill the goals of his followers [39]. Compensation as a process to understand what people do it together. Compensation is the influence between individuals, in certain situations and directly through the communication process to achieve one or several specific goals [40], [41].

Compensation is a personal attitude, which leads the implementation of activities to achieve the desired goals [42]. Compensation is a process that affects group activities that are organized to achieve common goals. Compensation can also be defined as the artistic or technical ability to make a group or person follow and obey their wishes. Compensation is a process that gives meaning (full meaning of compensation) to cooperation and is generated with the willingness to lead in achieving goals [43]. Compensation is the whole activity in order to influence people to be willing to work together to achieve the desired goals together, compensation is built on several basic properties [27].

This trait can be obtained partly from genetic factors and partly developed [44]. Compensation as the ability to influence the group towards achieving goals [40]. Whereas Griffin [31] defines compensation as a form of using influence without coercion to form group or organizational goals, motivate behavior towards these goals and help define group or organizational culture.

Compensation as the ability to influence a group to achieve a vision or set of goals [45]. Compensation as an individual's ability to influence, motivate and enable others to contribute to the effectiveness and success of the organization [37].

The hypotheses in this study are as follows:
$\mathrm{H}_{4}$ Compensation has a positive and significant effect on officer performance.

$\mathrm{H}_{5}$ Compensation has a positive and significant effect on job satisfaction.

\section{Performance}

The word performance is defined by several experts. Performance is a term that comes from the word job performance or actual performance actual (work performance or achievement achieved by someone) or work results in quality and quantity achieved by an employee in carrying out his duties following the responsibilities assigned to him [21].

Performance is a comparison of the results achieved with the participation of the labor union time (usually per hour) [46]. Performance is an expression such as output, efficiency and effectiveness which are often associated with productivity [47]. Performance is a systematic description of the advantages and disadvantages of individual or group work.

Although there are technical problems (such as format selection) and human problems (such as rater resistance, and the existence of relationship barriers between individuals), all of which cannot be resolved by performance evaluators [48]. Performance is a function of motivation and ability to complete a task or job where a person should have a certain degree of willingness and level of ability [49].

Performance is the willingness of a person or group to carry out an activity and improve it according to their responsibilities with the expected results [50]. Performance is the result of work that can be accomplished person or group of people from an organization following the authority and responsibilities of each in the context of efforts to achieve the goals of the organization in question legally, does not violate the law, and by moral and ethical [20].

Performance management is the overall activity carried out to improve the performance of a company or organization, including the performance of each individual and group that occurs in the company. Employee performance (job performance) is the employee's actual performance compared to the expected performance of the employee [22].

Expected work performance is besides researching even dimensions need standard performance that is formulated as a reference so that employees can see the performance according to their position compared to the standards made. In addition, it can also be seen the performance of these employees against other employees [37]. The term performance comes from the word job performance / actual performance (work performance or achievement achieved by someone). So according to the language performance can be interpreted as an achievement that appears as a form of work success in a person. The success of the performance is also determined by the work and ability of a person in that field. Job success is also related to one's job satisfaction [25].

A performance of person's is influenced by several factors. The several factors can affect performance, namely; ability, capacity, assistance, incentive, (e) environment, and validity. In conducting research on performance based on 
specific behavior (judgment performance evaluation), there are seven dimensions that need attention [51], among others: quality of work means that the quality of work will be achieved based on terms of suitability and readiness; quantity of work means the amount of work done in specified period water; Job knowledge means the breadth of knowledge about work and skills; Creativeness means the authenticity of ideas that arise and actions to solve problems that arise; cooperative, means the awareness to cooperate with others; initiative means the originality of the ideas submitted as an organizational program in the future; dependence) means that ideas are related to one another.

The hypotheses in this study are as follows:

$\mathrm{H}_{6}$ Compensation has a positive and significant effect on officer performance mediated by job satisfaction.

\section{Job satisfaction}

There are several definitions of job satisfaction put forward by several experts as in the following description. Job satisfaction is a pleasant emotional attitude and loves his job. This attitude is reflected by work morale, discipline, and work performance [52]. Job satisfaction is a general attitude towards someone's job which shows the difference between the number of awards received by workers and the amount they believe they should receive [45].

Job satisfaction is a pleasant emotional attitude and loves his job. This attitude is reflected by work morale, discipline, and work performance. Job satisfaction is enjoyed at work, outside work, and a combination of inside and outside work [45]. Job satisfaction is a feeling that can please someone at work or which can provide fulfillment of work values [23].

Job satisfaction is a person's feelings about work. This means that this kind of conception of job satisfaction sees job satisfaction as a result of human interaction with their work environment [45]. Job satisfaction at work will prioritize work rather than remuneration even though remuneration is important [53]. The job satisfaction is an employee attitude or emotional response. This definition implies that job satisfaction is not a single concept.

Moreover, a person can be relatively satisfied with one aspect of the job and dissatisfied with one or more aspects [49]. Job satisfaction is a positive and pleasant emotional condition as a result of an assessment of one's job or work experience [21].

Employee satisfaction can be influenced by several factors [23], namely; turnover, higher job satisfaction is related to the high and low level of employee turnover, and vice versa, dissatisfied employees usually have high turnover; Absenteeism, dissatisfied employees tend to be high absenteeism and unclear absence; Age, older employees tend to feel satisfied than younger employees. This is because older employees will experience adjusting to their work environment, while younger employees usually have good expectations about the world of work so that if gaps can cause them to be dissatisfied; At the job level, employees who have a higher level of work tend to feel more satisfied than this job shows better workability and also has a better income and vice versa; The size of the organization can affect employee job satisfaction because the size of the organization is related to employee coordination, communication, and participation.
Employee job satisfaction is much influenced by the attitude of the leader in compensation. Participation compensation provides job satisfaction for employees because employees participate actively in providing their opinions to determine company policy. Authoritarian compensation results in employee job dissatisfaction. Employee job satisfaction is the key to driving morale, discipline, and employee performance in supporting the realization of company goals.

There are many factors related to job satisfaction, namely autonomy and freedom, career benefits, opportunities for advancement, career development, compensation/salary, communication between employees and management, job contribution to organizational goals, feelings of security in the work environment, flexibility to balance life and work issues, job security, job specific training, management recognition of employee performance, meaning of work, networking opportunities to use abilities or expertise, organizational commitment to development, overall corporate culture, relationships among employees, relationships with direct superiors, the job itself, job diversity [45].

Several factors influence job satisfaction. The main things by keeping in mind the most important dimensions, namely, salary, the job itself, promotion, supervision, workgroup, and working conditions [51], [54]. Job satisfaction is influenced by five specific dimensions of work, namely salary, the job itself, promotion opportunities, supervision, and co-workers.

The hypotheses in this study are as follows:

$\mathrm{H}_{7} \quad$ Job satisfaction has a positive and significant effect on officer performance

\section{RESEARCH METHODS}

Based on the level of explanation, this research is regressive research with a quantitative approach. When viewed from the technique of obtaining data, this study used survey design. The survey design itself is a procedure in quantitative research that requires the researcher to administer a survey to a sample or the entire population to describe attitudes, opinions, behavior, or special characteristics of the population [55].

The population in this study was officers at 8 Public Health Centers in Pinrang District, totaling 322. Researchers took 220 people as samples. The data is sourced from the opinions or responses of respondents (staff who work at the Public Health Center) who have been determined by the researcher as a source of information (samples). Meanwhile, the data in the form of written documents are sourced from the Public Health Center in Pinrang Regency regarding employees or staff of the Community Health Center. The data collection method used in this study is a survey method by distributing a questionnaire or questionnaire to officers who are selected as respondents or samples. The method of analysis uses inferential statistics with the parametric data type and uses Structural Equation Modeling (SEM). 


\section{RESULTS}

The statistical results prove that the hypothesis that has been proposed shows that some hypotheses are proven to have an effect and are significant, while others do not affect because they have results below the critical value of the table, namely 1.96, the discussion is as follows:

$\mathrm{H}_{1} \quad$ Work environment has a positive and significant effect on officer performance

This first hypothesis is to measure the work environment variables on the performance of the officers. The results show that the hypothesis test between these two variables shows insignificant results because it shows the results of the t-value value which is lower than the t-table value, namely $0.00<1.96$, so that this result shows that the work environment does not have a significant effect on the performance of the officers. Researchers of this study reject the proposed hypothesis; the findings of this study provide evidence that the work environment does not affect officer performance. The results of this study are supported by previous research conducted [5], which analyzed the influence of work discipline, work environment, and work culture on teaching staff performance, that work discipline does not affect performance, the work environment does not affect performance, and work culture has no positive effect on the performance of the teaching staff. This research conducted [14] to determine the effect of the work environment and compensation on employee performance. The results showed that the work environment did not have a significant effect on employee performance while compensation had a significant value of $33.6 \%$, but it did not affect employee performance, namely 0.580 . So, it can be concluded that the work environment variable according to the respondent from the Public Health Center in Pinrang Regency does not affect performance.

$\mathrm{H}_{2}$ Work environment has a positive and significant effect on job satisfaction.

The second hypothesis test is between work environment variables on job satisfaction, the results show that the hypothesis test between these two variables shows the results of t-value 2.97> t table 1.96, the researcher concludes that work environment variables affect job satisfaction, which means that the proposed hypothesis is proven to be accepted. , that the work environment affects job satisfaction. The results of this study are supported by previous research conducted by [7], [9], [13], [47], which states that work environment variables have a positive and significant effect on officer performance. So it can be concluded that a good work environment can increase job satisfaction for Community Health Center officers.

$\mathrm{H}_{3} \quad$ Work environment has a positive and significant effect on officer performance mediated by job satisfaction.

Work environment on the performance of officers mediated by job satisfaction is significant at $33.6 \%$, but it has no effect on the performance of officers which is equal to 0.580 . So it can be concluded that the work environment variable according to the respondent does not affect performance.

$\mathrm{H}_{4}$ Compensation has a positive and significant effect on officer performance.

Effect of compensation on officer performance, based on the structural equation showing that the compensation variable on officer performance has a very strong influence value, because the number obtained exceeds the critical ttable value, namely 2.97> 1.96, the researchers conclude that compensation has a positive and significant effect on officer performance so that the proposed hypothesis is accepted. The results of this study are supported by previous research conducted by [3] that the better the compensation for Public Health Center officers, the better it can directly improve the performance of these officers.

$\mathrm{H}_{5}$ Compensation has a positive and significant effect on job satisfaction.

Effect of compensation on job satisfaction based on fifth hypothesis is to measure between compensation variables on job satisfaction and the result is that compensation has a significant effect on job satisfaction with a t-value of 2.31 greater than the critical value of t-table 1.96, so the researcher concludes that the compensation variable on job satisfaction has a significant effect. And that means if the study can prove the hypothesis proposed. The results of this study are supported by previous research conducted by [3], [4], [5], [8] that good compensation can increase job satisfaction.

$\mathrm{H}_{6}$ Compensation has a positive and significant effect on officer performance mediated by job satisfaction.

Effect of compensation on officer performance mediated by job satisfaction based on the sixth hypothesis test is to measure the influence between motivation variables on the performance of officers mediated by job satisfaction and the result is that it has a significant effect, this can be seen by looking at the t-value of -2.32 which is greater than the $\mathrm{t}$ table value of 1.96 , the researcher concludes that The results of this study that job satisfaction mediates the relationship between compensation to the performance of officers which has a significant effect and it means that this sixth test accepts the proposed hypothesis. The results of this study are supported by previous research conducted by [3 that job satisfaction mediates the relationship between compensation and performance of Community Health Center officers in Pinrang Regency.

$\mathrm{H}_{7} \quad$ Job satisfaction has a positive and significant effect on officer performance

Effect of job satisfaction on officer performance based on the last hypothesis test is between the job satisfaction variables on the performance of the officers. The result obtained is that the t-value -2.73 is greater than the t-table 1.96, with this result that the hypothesis test between job satisfaction and staff performance has an influence. The results of this study are also supported by previous research conducted by [3], [4], [10], [11], which state that job satisfaction has a significant effect on job satisfaction. So it can be concluded that employees who have high job satisfaction can directly improve the performance of these employees 


\section{CONCLUSIONS AND RECOMMENDATIONS}

The results of the research that has been conducted to determine the effect of work environment and compensation on performance through job satisfaction of Public Health Center Officers in Pinrang Regency, it can be concluded that the first hypothesis is proposed to measure work environment variables on employee performance. The results show that the hypothesis test between these two variables shows insignificant results because it shows the results of the t-value value which is lower than the t-table value, namely $0.00<1.96$, so this result shows that the work environment does not have a significant effect on the performance of the officers.

The effect of the work environment on job satisfaction shows that the hypothesis test between these two variables shows the results of t-value 2.97> t-table 1.96, so the researchers conclude that work environment variables have an effect on job satisfaction. The effect of work environment mediated by job satisfaction on officer performance is used to measure between work environment variables on officer performance mediated by job satisfaction and the result is that it has a significant effect. It can be seen that the variable path of job satisfaction on employee performance is 3.36, which is greater than the t-table value of 1.96 , so the researchers conclude that job satisfaction mediates the relationship between work environment and employee performance.

The effect of compensation on employee performance, that the compensation variable on employee performance has a strong influence value because the number found exceeds the critical value of $t$ table which is 1.96 with a value of 2.97. So the researchers concluded that the compensation variable has a significant effect on the performance of the officers.

The effect of compensation on job satisfaction is used to measure between compensation variables on job satisfaction and the result is that compensation has a significant effect on job satisfaction with a t-value of 2.31 greater than the critical value of t-table 1.96; the researcher concludes that the compensation variable on job satisfaction has significant influence.

The effect of compensation is mediated by job satisfaction on the performance of officers, the result is that it has a significant effect, this can be seen by looking at the $\mathrm{t}$-value -2.32 which is greater than the t-table value of 1.96 , the researcher concludes that the results of this study work satisfaction mediates the relationship between compensation for the performance of officers has a significant effect.

The effect of job satisfaction on officer performance, the result obtained is the value of t-value -2.73 is greater than $\mathrm{t}$ table $=1.96$, with these results that the hypothesis test between job satisfaction on officer performance has an influence.

This study recommends that the Public Health Center in Pinrang Regency must address the performance problems of these officers as best as possible, there is not a single Public Health Center that does not experience officer performance problems, but if it is not addressed properly, the Community Health Center will experience difficulties in carrying out its functions. Why? The manpower needed has to leave the
Community Health Center because it cannot be committed any longer, due to many things, one of which is a poor work environment, less assertive compensation and decreased job satisfaction which ultimately reduces the performance of officers and the impact can reduce quality.

Community Health Center services to be explained above; there are many things that can affect the performance of officers, such as work environment, compensation, and job satisfaction. The results show that the work environment can have a direct impact on the performance of the officers, so this needs to be considered such as fixing the lighting of the work space, rearranging the conditions of the workspace and so on.

Job satisfaction also plays an important role in employee performance, because if employees feel satisfied and all their needs are met, then employees can improve their performance. So that in the future there will be no more officer performance problems. For further researchers, the breadth of using variables is very important in determining the results that can improve the performance of officers; the ability to make questionnaires is the next most important thing to get accurate results.

The ability of respondents to answer the questionnaire properly is very important and necessary, not a few of them fill in poorly so that the results of the questionnaire are not optimal, so that the results obtained also have a good impact in presenting conclusions, therefore further researchers are expected to be able to complete as many theories as -the number of related variables is needed to describe the observed variables more perfectly, and we can see this information from journals published by previous researchers and reference books related to officer performance. There are still a lot of variables that have a good and significant level of trial results for further research, so the efforts and hard work of the next researcher in exploring the observed variables are very important, so that extra greater depth of theory and observation is needed in order to determine the variables that are better and can collect information more accurately and be accountable.

This information and knowledge can be obtained from journals that can be accounted for both nationally and internationally with recognized legality, so that researchers have richer and better research sources for conducting future research.

\section{REFERENCES}

[1] Central Bureau of Statistics of Pinrang Regency (2017). "Human Development Index for Pinrang Regency. Catalog. Pinrang.

[2] Social Security Administrative Body of Pinrang Regency. (2017) News Issue.

[3] Sulhan, M, Mukhlis and Yunus, Amri. (2014). "The Effect of Compensation Style and Work Motivation on Job Satisfaction and Its Impact on Employee Performance at the Aceh Finance Service". Journal of Postgraduate Management of Syiah Kuala University 3(2), 21-28.

[4] Lazuardy, Taufik, Yuwaldi Away, M. and Shabri Abd. Majid. (2014). "The Effect of Compensation and Organizational Culture on Job Satisfaction and Its Impact on the Performance of Civil Servants of the Aceh Barat Daya Regional Secretariat". Journal of Postgraduate Management of Syiah Kuala University. 3(2), 61-68.

[5] Pujiyanto, N. D., Puspita, D. R., and Harsanto, B. T. (2017). The influence of competence, motivation, work environment and perceptions of leadership style on the performance of family planning instructors. Society, Culture and Politics, 30 (3), 278-289. 
[6] Jankingthong and Rurkhum Gaol, CHR. Jimmi L. (2014). A to Z Human Capital Human Resource Management. Jakarta: PT Grasindo Member of IKAPI.

[7] Adzima, F., \& Sjahruddin, H. (2019). The Influence of Knowledge Management on Employee Performance.

[8] Aqsariyanti, L., Sjahruddin, H., \& Razak, N. (2019). The Effect of Work Ethics and Organizational Climate on Employee Performance.

[9] Reynaldi, R., Ridjal, S., and Sjahruddin, H. (2019). The role of organizational citizenship behavior in work performance: an investigation based on hotel employee survey. European Journal of Business and Management Research, 4(6).

[10] Saleh, Abbas, Mansyur Ramly, Mursalim Umar Gani, and Suriyanti. (2016). Factors Affecting the Job Satisfaction and Performance of Nurses Private Hospitals Class B in Makassar ". International Journal of Scientific and Technology Research. 05(10), 74-83.

[11] Toban, C., and Sjahruddin, H. (2016). The antecedent and consequence of Organizational Commitment and Job Satisfaction. Journal of Business and Management Sciences, 4(2), 26-33.

[12] Astuti, W. S., Sjahruddin, H., and Purnomo, S. (2019). Effect of Rewards and Punishment on Employee Performance.

[13] Syam, E. B., Pascawati, P. N. S., and Sjahruddin, H. (2020) Contribution of Islamic Leadership Style Dimensions to Teacher Performance. Journal of Economics and Business Dharma Andalas, 22 (2), 210-220.

[14] Logahan, J. M., Tjoe, T. F., and Naga, N. (2012). Analysis of the Influence of Work Environment and Compensation on Employee Performance of CV Mum Indonesia. Binus Business Review, 3 (1), 573-586.

[15] Sifatu, W. O., Sjahruddin, H., Fajriah, Y., Dwijendra, N. K. A., and Santoso, A. (2020). Innovative Work Behaviors in Pharmacies of Indonesia: Role of Employee Voice, Generational Diversity Management and Employee Engagement. Systematic Reviews in Pharmacy, 11(2), 725-734.

[16] Gustavo, Wilchesand. (1995). Disasters and the Environment. UNDPDHA (Disaster Management Training Program).

[17] Singh, YK (2006). Environmental Science. New Delhi: New Age International (P). Ltd. Publisher.United Nations Development Program. 2016. Human Development Index Report: Indonesia. accessed on 12 December 2017.

[18] Republic of Indonesia (2009). The Law Number 32. Concerning Environmental Protection and Management.

[19] Soemarwoto, Otto. (2001). Self-Regulating A New Paradigm of Environmental Management. Yogyakarta: Gadjah Mada University Press.

[20] Carry, S. Beecher. (1993). Human Capital. Chicago: The University of Chicago Press.

[21] Prawirosentono, Suyadi and Dewi Primasari. (2017). Human Resource Management Employee Performance and Motivation to Build a Competitive Organization in the World Free Trade Era Yogyakarta: BPFE

[22] Mangkunegara, A. Anwar Prabu. (2017), Human Resources Performance Evaluation, Bandung: PT Refika Aditama.

[23] Simanjuntak, Payaman J. (2005). Management and Job Evaluation Jakarta: FE-UI Publishing Institute.

[24] Isyandi, B. (2004). Human Resource Management in a Globa Perspective.Pekanbaru, Riau University Press.

[25] Mardiana. (2005). Production Management. Jakarta: Publisher IPW Publishing Agency.

[26] Mangkunegara, A. Anwar Prabu. (2000), Company Human Resource Management, Bandung: Youth Rosdakarya.

[27] Siagian, Sondang P. (2006). Theory and Compensation. Jakarta: Rineka Cipta.

[28] Sedarmayanti. (2017). Planning and Human Resource Development to Increase Competency, Performance and Work Productivity. Bandung: PT Refika Aditama.

[29] Sedarmayanti. (2004). Human Resources and Work Productivity. Bandung: Mandar Maju.

[30] Tambunan, Toman S. (2015). Leaders and Compensation. Yogyakarta: Graha Science.

[31] Griffin, Ricky. W. (2004). Management (translation): Volume 1 and 2. Jakarta: Erlangga.

[32] Kotler, Philip and Kevin Lane Killer. (2007). Marketing Managemen (translation). Jakarta: Erlangga.

[33] Davis, Keith and John W. Newstrom. (1991). Behavior in Organizations (translation). Jakarta: Erlangga.

[34] Culligan, Matthew J. (1996). Management "Back to Basics" (translation). Jakarta: Spectrum.

[35] Covey, Sthephen R. (2008). The $8^{\text {th }}$ Habit: Beyond Effectiveness, Reaching Greatness (translation). Jakarta: Gramedia Pustaka Utama.
[36] Hock, Dee. (2005). Chaordic Compensation Art. A Leader To Leader Guide: Mission and Compensation (translation). Jakarta: Elex Media Komputindo.

[37] Daryanto, (2013). Effective Learning Innovations. Bandung: Yurma Widya.

[38] Yukl, Gary. (2010). Compensation in Organization Fifth Edition. Jakarta: PT. index

[39] Hemphill, J. K., \& Coons, A. E. (1957). Leader behavior: Its description and measurement. Administrative Science Quarterly, 6 38.

[40] Burns, JM (1978). Leadership. New York: Harper Row.

[41] Robbins, SP, and TA, Judge. (2007). Organizational Behavior, Book 1. Jakarta: Salemba Empat.

[42] Tannenbaum, R., Weschler, IR, and Massarik, F. (1961). Leadership and Organization. New York: McGraw-Hill.

[43] Jacobs, TO and Jaques E. (1990). Military Executive Leadership. KE Clark MB Clark (Dds), Measures of Leadership, NJ, Leadership Library of America.

[44] Terry GR (1977). Principle of Management. New York: Richard.D. Irwin, Inc.

[45] Amir, M. Taufik. (2017). Organizational behavior. Jakarta: Kencana.

[46] Robbins, SP, and TA, Judge. (2008). Organizational Behavior, Book 2. Jakarta: Salemba Empat.

[47] Balouch, R., \& Hassan, F. (2014). Determinants of job satisfaction and its impact on employee performance and turnover intentions. International journal of learning and development, 4(2), 120-140.

[48] Gomez-Meija, Luis R. Balkin, David. Cardy, Robert L. (1995) Managing Human Resources. New Jersey: Prentice Hall Inc.

[49] Suwatno, H. and Donni Juni Priansa. (2011). Human Resources Management in Public and Business Organizations. Bandung: Alfabeta.

[50] Kinicki, Anggello and R. Kreitner. (2005). Organizational Behavior Key Concepts Skills and Best Practice. New York: McGraw-Hill.

[51] Garry, Dessler. (2004). Human Resources Management. New York Mc. Graw-Hill Companies.

[52] Luthans, F. (2005). Organizational Behavior [10th edition]. Yogyakarta: Andi Press.

[53] Fathoni, Abdurahmat DV. (2006). Human Resource Management. Jakarta: Rineka Cipta.

[54] As'ad, Moh. (2004), Industrial Psychology. Yogyakarta: Liberal.

[55] Creswell, J. W. (2002). Educational research: Planning, conducting, and evaluating quantitative (pp. 146-166). Upper Saddle River, NJ: Prentice Hall. 